\title{
ANALISIS KONTEKS WILAYAH TERHADAP PERCERAIAN DI PROVINSI JAWA TIMUR
}

\author{
Ghina Salsabila ${ }^{1}$, Abdur Rofi ${ }^{* *}$ \\ 'Depertemen Geografi Lingkungan, Fakultas Geografi, Universitas Gadjah Mada, \\ Yogyakarta 55281, Indonesia \\ *)E-mail: abdurrofi@ugm.ac.id
}

\begin{abstract}
Abstrak
Kajian terhadap terjadinya perceraian lebih banyak dilihat dari faktor individual dan rumah tangga dan kurang banyak dikaji dari aspek konteks wilayah. Penelitian ini bertujuan untuk menganalisis konteks wilayah dengan menganalisis kecenderungan dan sebaran spasial tingkat perceraian di Jawa Timur tahun 2012-2020 dan menganalisis hubungan antara faktor sosial ekonomi wilayah dengan tingkat perceraian di Jawa Timur. Data yang digunakan dalam penelitian adalah data sekunder dari publikasi Badan Pusat Statistik. Analisis kecenderungan dan persebaran tingkat perceraian di Jawa Timur dilakukan secara deskriptif dan menggunakan indeks Hoover. Sementara itu, analisis hubungan antara tingkat perceraian dan faktor sosial ekonomi wilayah menggunakan uji korelasi Pearson. Penelitian ini menemukan adanya peningkatan angka perceraian di Jawa Timur tahun 2012-2020 dengan persebaran tingkat perceraian yang tidak merata dan cenderung terkonsentrasi di wilayah tertentu. Hal tersebut tercermin dari semakin meningkatnya indeks Hoover. Faktor konteks wilayah di Jawa Timur yang berhubungan signifikan dengan tingkat perceraian adalah rata-rata lama sekolah dan persentase penduduk miskin. Perceraian memiliki korelasi positif dengan rata-rata lama sekolah dan memiliki korelasi negatif dengan persentase penduduk miskin. Penelitian ini merekomendasikan cara mengurangi tingkat perceraian di Jawa Timur, yaitu tidak hanya dilakukan dengan memperbaiki tingkat pendidikan dan kemakmuran penduduk, tetapi juga memperbaiki kualitas pendidikan dan mendorong dekonsentrasi pendidikan dan kemakmuran.
\end{abstract}

Kata kunci: ekonomi, perceraian, sosial, spasial, wilayah

\section{Regional Context Analysis of Divorce in East Java Province}

\begin{abstract}
Studies on the causes of divorce are mostly viewed from individuals-household factors and less studied from aspects of regional context. This study aims to analyze regional context by examining the trend and spatial distribution of divorce rates and seeks the relationship between regional socioeconomic factors and divorce rates in East Java in 2012-2020. This study used secondary data from the publications of Statistics Indonesia. The trend and distribution of divorce rates in East Java were carried out descriptively and analyzed using the Hoover index. Meanwhile, the relationship between the divorce rate and regional socioeconomic factors was analyzed using the Pearson correlation test. This study found that divorce rates in East Java from 2012-2020 tended to increase. Meanwhile, the distribution of divorce rates was uneven and tended to experience concentration in certain areas, seen from the increasing Hoover index. Regional context factors that were correlated significantly with the divorce rate in East Java were the average years of schooling and the percentage of poor people. Divorce had a positive correlation with the average years of schooling and a negative correlation with the percentage of poor people. This study recommends ways to reduce the divorce rate in East Java, which is not only by improving the education level and prosperity of the population but also by improving the quality of education and encouraging education deconcentration and prosperity.
\end{abstract}

Keywords: divorce, economic, regional, social, spatial

\section{PENDAHULUAN}

Seiring dengan perubahan sosial budaya, makna perkawinan pun telah mengalami perubahan, dan perceraian dipandang sebagai suatu perbuatan yang wajar dan alamiah tanpa mempertimbangkan akibat dan dampaknya (Khotimah \& Ahmad, 2019). Fenomena peningkatan perceraian ini terjadi hampir di seluruh dunia termasuk pada komunitas masyarakat di negara berkembang seperti Indonesia. Beberapa studi yang mengkaji penyebab tingginya perceraian di Indonesia yang masuk ke Pengadilan Agama menunjukkan penyebab terjadinya perceraian di Indonesia karena faktor ekonomi, kekerasan dalam rumah tangga, termasuk di dalamnya perkawinan paksa dan perkawinan di bawah 
umur (Rais, 2014; Thalib \& Lestari, 2017). Studi tersebut lebih banyak menyoroti faktor individual dan rumah tangga penyebab terjadinya perceraian.

Peristiwa perceraian yang tinggi di Indonesia tidak hanya terjadi di beberapa provinsi tetapi hampir mencakup keseluruhan provinsi di Indonesia. Tiga provinsi dengan angka perceraian tertinggi adalah Jawa Barat, Jawa Timur, dan Jawa Tengah (Tristanto, 2020). Hal ini menimbulkan kekhawatiran karena pernikahan tidak lagi dianggap sakral dan perceraian dapat dengan mudah dikabulkan. Pergeseran budaya yang semakin terbuka, berkurangnya makna dan nilai pernikahan, serta pemahaman agama yang kurang baik menjadi salah satu pemicu/pendorong meningkatnya prevalensi perceraian di Indonesia (Kustini \& Rosidah, 2016). Sepanjang tahun 2010-2015 telah terjadi peningkatan angka perceraian di Indonesia sebesar 15-20 persen (Choiriah, 2016). Data lain menunjukan bahwa pada 2015 sebanyak 5,89 persen pasangan suami istri bercerai (hidup), denyan jumlah sekitar 3,9 juta dari total 67,2 juta rumah tangga. Pada 2020 , persentase perceraian naik menjadi 6,4 persen dari 72,9 juta rumah tangga. Perkembangan zaman globalisasi membawa perubahan dalam berbagai bidang kehidupan manusia, termasuk perubahan dalam berbagai bidang sosial masyarakat. Perceraian dapat menjadi salah satu dampak negatif dari perubahan tersebut disebabkan oleh merosotnya nilai-nilai normatif dalam masyarakat (Dewi \& Utami, 2018).

Perceraian sendiri memiliki dampak positif dan negatif. Dampak positif dari perceraian adalah menjadi salah satu kontributor dalam penurunan fertilitas. Hal tersebut dikarenakan dapat menurunkan fertilitas perempuan yang mengarah pada semakin rendahnya atau berkurangnya hubungan seksual sehingga menurunkan peluang hamil (Uddin \& Hosain, 2013). Namun demikian, dampak negatif perceraian juga membawa risiko besar bagi anak, baik secara psikologis, kesehatan, maupun akademis (Dewi \& Utami, 2018). Perceraian menjadi pilihan pasangan ketika pernikahan dinilai tidak berhasil (Hackstaff, 1999). Perceraian terjadi karena adanya suatu alasan yang melatarbelakanginya (Wijayanti, 2021). Adanya perubahan dalam tingkat perceraian dikaitkan dengan perubahan peningkatan pendidikan, perubahan partisipasi angkatan kerja perempuan, perubahan sifat dalam seleksi pasangan, perubahan usia saat pernikahan, tingkat dukungan sosial bagi perempuan yang diceraikan, perubahan dalam agama, dan hukum sipil yang mengatur perceraian serta perubahan harapan hidup (Dommaraju \& Jones, 2011).

Secara ringkas faktor terjadinya perceraian dapat dilihat pada tiga tingkat, yaitu karena faktor individual, keluarga, dan wilayah. Faktor individu yang memengaruhi terjadinya perceraian adalah pendidikan, pekerjaan, pendapatan, umur, inteligensi, tinggi badan, dan usia kawin pertama (Ambert, 2009; Becker, 1993). Becker (1993) menyebutkan bahwa orang-orang yang menikah muda memiliki probabilitas bercerai yang lebih tinggi. Usia kawin pertama bergantung pada tingkat bias ekspektasi (harapan). Mereka yang memiliki pendapatan rendah bersama dengan tingkat pendidikan rendah merupakan faktor risiko lain terjadinya perceraian (Clark \& Crompton, 2006). Peningkatan pendidikan memiliki efek yang ambigu terhadap kemungkinan perceraian dan pernikahan ulang. Pendidikan mengurangi pembagian kerja antar pasangan (menurunkan keuntungan perkawinan) tetapi meningkatkan keuntungan perkawinan dari segi pembagian kerja misalnya pada perempuan berpendidikan tinggi (Becker et al., 1977). Efek pendidikan menunjukkan bahwa orang dengan tingkat pendidikan yang lebih tinggi memiliki pernikahan yang lebih stabil dibandingkan dengan tingkat pendidikan yang lebih rendah (Amato, 2010). Pada tingkat individu, istri dengan riwayat pernah berpartisipasi dalam angkatan kerja lebih mungkin untuk mengajukan perceraian daripada istri yang tidak bekerja.

Faktor keluarga yang memengaruhi terjadinya perceraian di antarnya adalah perceraian orang tua, jumlah anak, dan pembagian kerja dalam rumah tangga (Ambert, 2009). Keputusan individu tentang menikah atau bercerai, atau merencanakan kehamilan dapat bervariasi tergantung pada situasi pekerjaan pasangan (González-Val \& Marcén, 2018). Peningkatan pekerjaan dan penghasilan perempuan dianggap mengurangi biaya perceraian dan memberikan istri alat ekonomi untuk mengakhiri perkawinan yang tidak bahagia.

Selain faktor individu dan keluarga, faktor wilayah juga diduga berpengaruh terhadap terjadinya perceraian. Pengaruh ini didasarkan bahwa masing-masing wilayah memiliki faktor sosial, ekonomi, demografi, dan budaya yang berbeda-beda. Eksplorasi perbedaan wilayah dalam menjelaskan terjadinya perceraian dapat digunakan untuk menjelaskan lebih jauh teori tentang pernikahan dan keluarga pada masyarakat maju. Florida (2008) menyebutkan bahwa lokasi geografis adalah salah satu penentu paling penting dari kesejahteraan, 
khususnya mengenai pengembangan hubungan pribadi. Hal tersebut dengan asumsi bahwa tempat tinggal dapat memengaruhi pendapatan yang akan diperoleh, orang-orang yang ditemui, lingkup pertemanan, mitra yang dipilih, dan pilihan yang tersedia untuk anak-anak dan keluarga. Letak tempat tinggal memiliki lebih banyak pengaruh pada peluang untuk bertemu pasangan hidup. Namun demikian, jarak geografis juga dapat menjadi penghalang utama bagi pasar perkawinan yang efisien. Florida (2008) menyebutkan bahwa lokasi geografi memengaruhi pilihan orang untuk menikah dan bercerai. Beberapa tempat menawarkan pasar tenaga kerja dan prospek karir yang lebih baik, apresiasi real estat yang lebih tinggi, dan peluang investasi serta penghasilan yang lebih tinggi. Hal ini termasuk menawarkan pasar perkawinan yang lebih menjanjikan dan lingkungan yang lebih baik untuk membesarkan anak-anak. Wilayah memiliki keragaman perkembangan kondisi sosial dan ekonomi termasuk juga tradisi mengenai pernikahan dan keluarga serta penerimaan tentang perceraian. Selain itu, wilayah memiliki keragaman dan perkembangan kondisi sosial dan ekonomi yang berbeda-beda, termasuk terkait dengan tradisi mengenai pernikahan dan keluarga serta penerimaan masyarakat terhadap perceraian.

Perceraian juga terkait dengan adanya ketimpangan gender dan kesadaran gender di suatu wilayah. Semakin tinggi kesadaran gender masyarakat terutama kelompok perempuan, maka semakin tinggi kasus gugat cerai (Sa'adah, 2018). Di dalam masyarakat yang dicirikan oleh tingkat perceraian yang tinggi, perempuan biasanya lebih mandiri secara finansial daripada laki-laki di dalam suatu perkawinan dan oleh karena itu mereka lebih memilih berpartisipasi dalam angkatan kerja bekerja (Diekmann, 1994; Hou \& Omwanda, 1997). Studi lain menunjukkan di wilayah dengan tingkat partisipasi kerja perempuan yang tinggi dan tingkat fertilitas yang rendah cenderung terdapat peningkatan ketidakstabilan pernikahan yang dapat berujung pada perceraian (Becker et al., 1977). Yodanis (2005) juga menyebutkan bahwa budaya pernikahan dan perceraian memiliki ciri yang berbeda. Pada masyarakat yang memandang budaya pernikahan tinggi, perempuan akan tetap mempertahankan pernikahan meskipun berada dalam hubungan tidak puas atau tidak setara. Sementara itu, laki-laki berisiko kehilangan perempuan apabila di dalam hubungan itu tidak terdapat kesetaraan dan masyarakat menerima adanya perceraian. Frisco dan Williams (2003) menyebutkan pula bahwa ketika perempuan percaya bahwa mereka melakukan sesuatu lebih dari yang seharusnya dari peran dan fungsi laki-laki dalam rumah tangga, perempuan dua kali lebih mungkin untuk melakukan perceraian.

Aspek spasial lain yang terkait dengan perceraian adalah mobilitas penduduk antar wilayah. Mobilitas penduduk diduga memiliki keterkaitan dengan perceraian pada tingkat negara, provinsi, dan kabupaten. Asumsinya adalah bahwa wilayah yang mengalami perubahan sosial yang cepat dan mengalami industrialisasi dapat menarik migran dari wilayah lain, dan pada saat yang sama terjadi mobilitas dalam rangka mencari peluang hidup yang lebih baik. Dasar pemikiran yang mendasari penggunaan mobilitas penduduk sebagai variabel dalam terjadinya perpisahan adalah adanya disorganisasi sosial (Fischer, 1975). Difurio et al. (2012) menambahkan bahwa faktor ekonomi dari suatu wilayah dapat menjelaskan fenomena perceraian suatu wilayah. Variabel seperti pengangguran, pendapatan per kapita, agama, dan ekonomi regional memengaruhi tingkat perceraian di suatu wilayah. Becker et al. (1977) memasukkan faktor ekonomi untuk menjelaskan keputusan menikah sebagai pembanding bagi seseorang ketika mereka tidak menikah (single). Becker menyebutkan bahwa keputusan bercerai didasarkan pada keuntungan yang didapatkan ketika masih menikah atau bercerai. Faktor yang memengaruhi perceraian pada dasarnya berubah dari waktu ke waktu. Faktor eksternal seperti fluktuasi dari siklus bisnis nasional atau regional mungkin memiliki hubungan yang tidak langsung, akan tetapi dapat menjelaskan secara signifikan tren dari perceraian (DiFurio et al., 2012). Industrialisasi, menurunnya usia kawin pertama, peningkatan usia harapan hidup, penurunan fertilitas, dan peningkatan partisipasi angkatan kerja perempuan berhubungan dengan peningkatan angka perceraian. Selain itu, rasio jenis kelamin juga memiliki dampak terhadap perceraian. Lebih lanjut, pada masyarakat dengan rasio jenis kelamin tinggi, perempuan akan sangat dihargai terutama untuk perannya sebagai istri dan ibu. Hal ini disebabkan karena laki-laki tidak memiliki kesempatan untuk membentuk hubungan alternatif dengan perempuan, dan mereka akan lebih rendah dalam membuat keputusan bercerai (Trent \& South, 1989). Pada kajian ekonomi, efek dari siklus bisnis biasanya diukur dalam hal tingkat pengangguran atau indeks harga dan kemiskinan, yang juga memiliki implikasi sosial dan individu yang kuat, misalnya kondisi ekonomi yang memengaruhi stabilitas keluarga. 
Sebagian besar penelitian mengenai perceraian terutama di Indonesia lebih berfokus pada kajian secara individu dan keluarga (Ambert, 2009; González-Val \& Marcén, 2018; Matondan, 2014; Rais, 2014; Thalib \& Lestari, 2017; Tristanto, 2020; Wijayanti, 2021). Belum banyak yang mengkaji keterkaitan secara umum kondisi kewilayahan dengan tren peningkatan perceraian di suatu wilayah. Berdasarkan hal tersebut, penelitian ini bertujuan untuk mengisi kekosongan penelitian terkait dengan perceraian terutama di Indonesia dengan melihat faktor wilayah terjadinya perceraian. Tujuan penelitian ini adalah untuk mengetahui kecenderungan dan sebaran spasial tingkat perceraian di Jawa Timur, dan mengidentifikasi faktor-faktor konteks wilayah yang berhubungan dengan tingkat perceraian. Berdasarkan data 34 provinsi yang ada di Indonesia, tingkat perceraian Jawa Timur merupakan yang paling tinggi dengan sumbangan sebesar 47 persen dari total perceraian di Indonesia. Data menunjukkan bahwa Jawa Timur memiliki kasus yang paling tinggi di Indonesia, dengan jumlah kasus dari tahun 2012-2016 tercatat sebanyak 91.449, 85.484, 89.406, 87.149, dan 86.491 kasus (BPS, 2017a).

\section{METODE}

Lokasi penelitian ini dipilih secara purposive yaitu Provinsi Jawa Timur. Provinsi Jawa Timur dipilih sebagai lokasi penelitian dengan beberapa pertimbangan. Pertama, jumlah kasus perceraian di Jawa Timur adalah paling tinggi di Indonesia dan tren tingkat perceraian yang terus meningkat dari tahun ke tahun (BPS, 2017a). Kedua, Provinsi Jawa Timur merupakan salah satu provinsi yang memiliki tingkat perkawinan usia dini yang paling tinggi di Indonesia. Tercatat sebanyak 39,43 persen perempuan Jawa Timur yang menikah usia dini, kemudian diikuti oleh Kalimantan Selatan sebesar 35,48 persen, Jambi sebesar $30,63 \%$, dan Jawa Barat sebesar 36 persen (Arimurti \& Nurmala, 2017). Ketiga, Jawa Timur memiliki 38 kabupaten yang paling banyak di Indonesia dengan empat wilayah kebudayaan yang berbeda yaitu Arekan, Mataraman, Madura, dan Pandalungan (Setyaningsih, 2013)

Penelitian ini menggunakan data sekunder dari publikasi BPS. Data yang digunakan meliputi data publikasi dari Statistik Kesejahteraan Jawa Timur tahun 2012-2020 (BPS, 2012, 2013, 2014, 2015, 2017c, 2018, 2019, 2020). Selain itu, untuk mengetahui faktor-faktor yang berhubungan dengan terjadinya perceraian, penelitian ini menggunakan beberapa variabel bebas yang menggambarkan konteks wilayah, yaitu rerata usia kawin pertama, rerata lama sekolah, Tingkat Pengangguran Terbuka (TPT) laki-laki, Tingkat Partisipasi Angkatan Kerja (TPAK) perempuan, dan persentase penduduk miskin di tingkat kabupaten/kota. Data-data tersebut diambil dari Statistik Kesejahteraan Jawa Timur 2017, Statistik Dasar Publikasi BPS Jawa Timur 2017, dan Publikasi Keadaan Angkatan Kerja Jawa Timur 2017. Data sekunder tersebut kemudian dipilah sesuai dengan variabel yang dikaji untuk menjawab tujuan penelitian ini. Jumlah unit analisis yang digunakan sebanyak 38 kabupaten atau kota yang ada di Jawa Timur.

Penelitian ini menggunakan batasan tingkat perceraian yang diukur dari persentase penduduk berstatus cerai hidup dengan penduduk pernah kawin di masing-masing kabupaten di Jawa Timur. Cerai hidup adalah seseorang yang telah berpisah sebagai suamiistri karena bercerai dan belum kawin lagi. Hal ini mengacu pada responden yang mengaku bercerai walaupun belum resmi secara hukum, namun tidak termasuk mereka yang hanya hidup terpisah tetapi masih berstatus kawin, misalnya suami/istri ditinggalkan oleh pasangan ke tempat lain karena sekolah, bekerja, mencari pekerjaan, atau untuk keperluan lain.

Tujuan pertama dari penelitian ini yaitu untuk menganalisis tren tingkat perceraian dan distribusi perceraian yang terjadi di Jawa Timur. Tren tingkat perceraian dianalisis secara deskriptif dari tahun 2012-2020. Sementara itu, analisis distribusi spasial dilakukan melalui analisis spasial peta dan analisis indeks Hoover. Analisis spasial untuk melihat pola spasial juga akan dikaitkan dengan wilayah melalui penggambaran kondisi fisik, sosial, ataupun lingkungan. Hal ini digunakan untuk melihat kaitan antara aspek geografi (wilayah) dan ciri yang berbeda dalam mendeskripsikan fenomena di suatu wilayah. Sementara itu, analisis menggunakan indeks Hoover digunakan untuk melihat kecenderungan konsentrasi dan dekonsentrasi perceraian di Jawa Timur dengan memperhitungkan kasus perceraian di tingkat kabupaten dan mempertimbangkan luas wilayah tiap kabupaten. Indeks Hoover merupakan salah satu indeks yang dapat mengukur konsentrasi suatu populasi di suatu wilayah dengan mempertimbangkan luas wilayah serta cocok digunakan untuk menggambarkan pola konsentrasi populasi. Rumus Indeks Hoover ialah sebagai berikut (Rogerson \& Plane, 2013). Indeks Hoover memiliki nilai dari $0-100$. Semakin besar nilai indeks menunjukkan semakin besarnya derajat konsentrasi suatu populasi. 
$H=50 \sum_{i=1}^{k} \mathrm{Ipi}-\mathrm{aiI}$

Keterangan :

$\mathrm{H}=$ Indeks Hoover

$\mathrm{pi}=\%$ penduduk berstatus cerai di wilayah $\mathrm{i}$

$\mathrm{ai}=\%$ luas wilayah $\mathrm{i}$

$\mathrm{k}=$ total jumlah wilayah (38 kabupaten/kota)

Analisis untuk melihat hubungan antara faktor wilayah dan tingkat perceraian dilakukan dengan menggunakan korelasi Pearson. Faktorfaktor wilayah yang digunakan untuk melihat hubungan dengan perceraian diambil dengan mempertimbangkan ketersediaan data yang ada yaitu rerata usia kawin pertama, tingkat pendidikan, tingkat pengangguran terbuka (TPT) laki-laki, tingkat partisipasi angkatan kerja (TPAK) perempuan, dan tingkat kemiskinan. Variabel pengangguran menggunalkan data pengangguran laki-laki karena laki-laki identik sebagai kepala rumah tangga dan pencari nafkah utama (breadwinner). Sebelum dilakukan analisis korelasi, dilakukan uji normalitas dengan Saphiro Wllk karena data yang digunakan berukuran kecil (tiga puluh depan kabupaten).

HASIL

\section{Tren Tingkat Perceraian}

Penelitian ini menunjukkan bahwa tingkat perceraian di Jawa Timur dari tahun 2012 hingga 2017 cenderung meningkat (Gambar 1). Berdasarkan data aktual kejadian perceraian yang tercatat di BPS dan dikumpulkan oleh Badan Peradilan Agama, Jawa Timur memiliki jumlah kasus perceraian tertinggi dibandingkan provinsi lain di Indonesia dari tahun 2012 hingga 2016. Namun demikian, terdapat kecenderungan penurunan jumlah yaitu sebanyak 91.449 kasus pada tahun 2012 menjadi 86.491 kasus pada tahun 2016 .

\section{Persebaran Tingkat Perceraian di Jawa Timur}

Peta tingkat perceraian Jawa Timur tahun 2012 menunjukkan bahwa kabupaten/kota yang memiliki persentase perceraian tinggi berada di bagian tengah dan barat meliputi Kabupaten Ponorogo, Tulungagung, Kediri, Nganjuk, Mojokerto, Malang, Pasuruan, Lumajang, Probolinggo, Situbondo, Banyuwangi, Pamekasan, Sampang, Sumenep, serta Kota Batu, Pasuruan, Mojokerto, dan Probolinggo. Sementara itu, pada tahun 2017 persentase perceraian yang tinggi juga berada pada bagian yang sama akan tetapi cenderung berkumpul ke arah timur dari provinsi Jawa Timur meliputi Kabupaten Kediri, Nganjuk, Jombang, Blitar, Lumajang, Probolinggo, Jember, Situbondo, Banyuwangi serta Kota Madiun, Kediri, Blitar, Malang, Batu, Surabaya dan Mojokerto (Gambar 2).

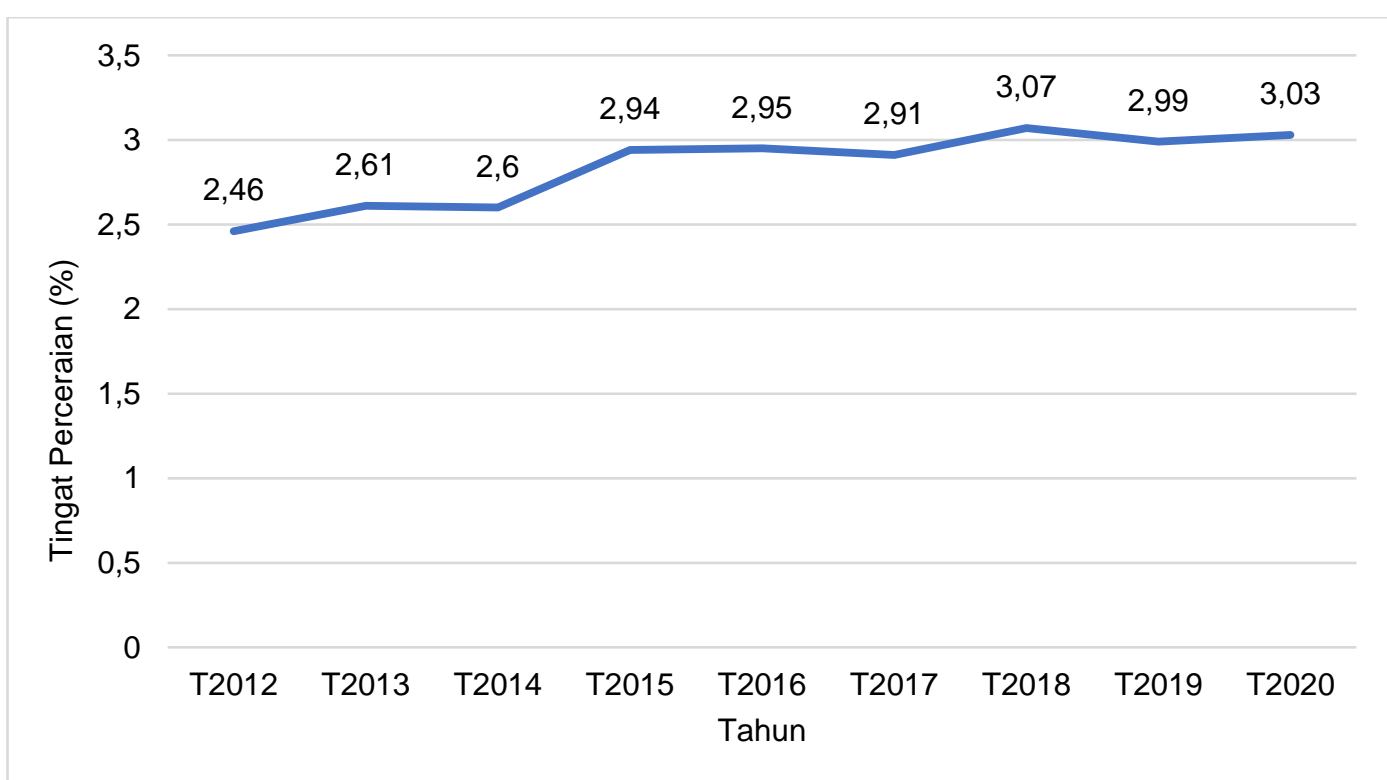

Sumber: Diolah dari BPS ( 2012, 2013, 2014, 2015, 2017c, 2018,2019,2020)

Gambar 1 Kecenderungan persentase perceraian di Jawa Timur tahun 2012-2017 

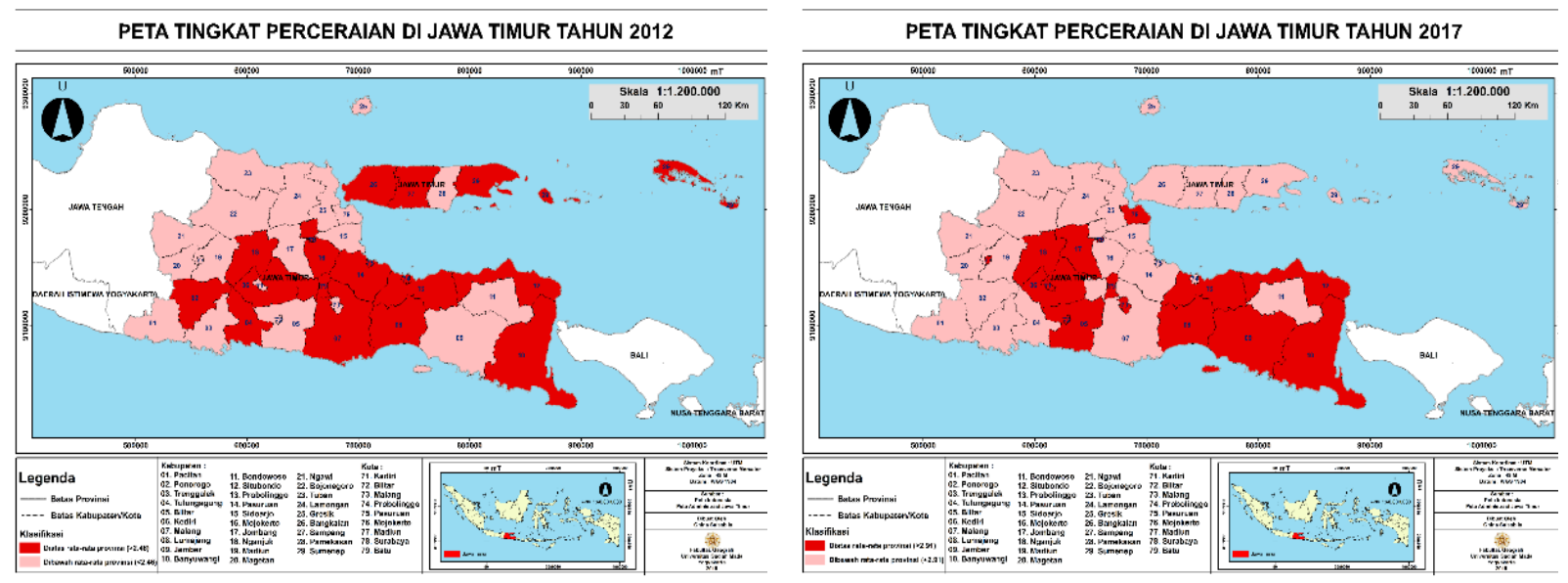

Gambar 2 Persebaran tingkat perceraian di Jawa Timur tahun 2012 dan 2017

Hasil perhitungan indeks Hoover menunjukkan bahwa perceraian di Jawa Timur cenderung terkonsentrasi di wilayah tertentu. Hal ini ditandai dari nilai indeks Hoover yang cenderung mendekati nilai 100 dari tahun 2012-2017 (Gambar 3). Daerah-daerah dengan tingkat perceraian tinggi banyak berada di bagian timur. Pola lainnya yaitu perceraian terjadi di daerah kota madya. Tingkat perceraian di kota mengalami perubahan yang cukup signifikan. Pada tahun 2012, dari total sembilan kota di Jawa timur, terdapat empat kota yang memiliki persentase perceraian tinggi, kemudian berubah menjadi tujuh kota pada tahun 2017. Kota-kota pada tahun 2012 yang memiliki tingkat perceraian rendah mengalami peningkatan pada tahun 2017 dan sebaliknya. Kota-kota tersebut pada tahun 2012 adalah Kota Mojokerto, Batu, Probolinggo, dan Pasuruan, sedangkan pada tahun 2017 yaitu Kota Madiun, Kediri, Blitar, Malang, Batu, Surabaya, dan Mojokerto. Terlepas dari adanya kabupaten yang memiliki tingkat perceraian tinggi pula, kejadian perceraian yang tinggi di kota memiliki keunikan tersendiri. Selain pola yang telah disebutkan, terdapat pola lain yang dapat diamati dari daerah kota madya.

\section{Faktor yang Berhubungan dengan Perceraian}

Faktor wilayah yang digunakan dalam penelitian ini didasarkan pada data tiga puluh delapan kabupaten atau kota di Provinsi Jawa Timur. Faktor wilayah yang digunakan dalam penelitian ini adalah rata-rata usia kawin pertama, lama sekolah, proporsi penduduk miskin, tingkat pengangguran terbuka (TPT) bagi laki-laki, dan tingkat Partisipasi Angkatan Kerja (TPAK) perempuan. Data yang digunakan dalam penelitian ini sudah melalui uji normalitas dan menunjukkan bahwa data yang digunakan terdistribusi normal dengan nilai signifikansi masing-masing variabel lebih besar dari 0,05. Berdasarkan hasil korelasi Pearson dapat diketahui bahwa korelasi antara rata-rata usia kawin pertama dengan tingkat perceraian di Jawa Timur memiliki arah yang positif dengan nilai 0,25 (Tabel 1). Arah positif menunjukkan bahwa rata-rata usia kawin pertama berbanding lurus dengan perceraian. Hal ini berarti semakin tinggi usia kawin pertama, semakin tinggi tingkat perceraian. Meskipun demikian, hubungannya tidak signifikan $(p>0,05)$. Dengan demikian, ratarata usia kawin pertama tidak memiliki hubungan yang kuat dan signifikan dengan perceraian.

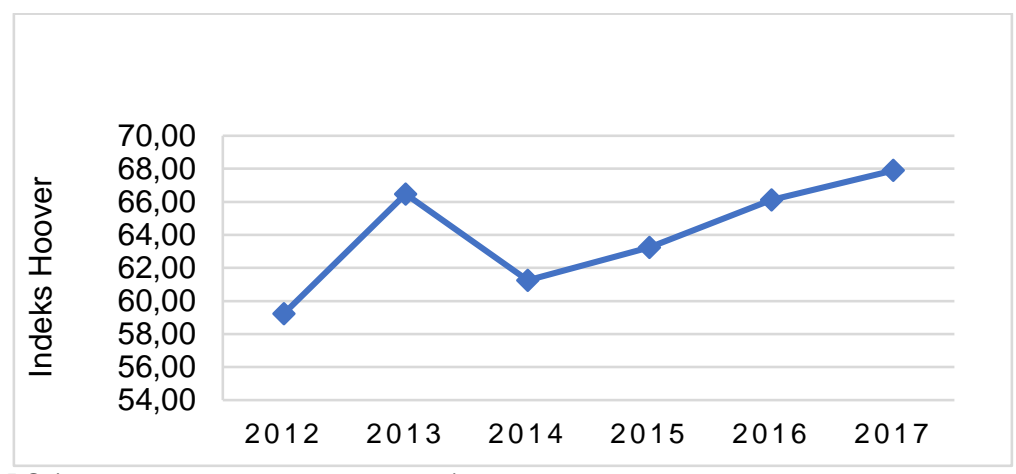

Sumber : Diolah dari BPS ( 2012, 2013, 2014, 2015, 2017c) 
Tabel 1 Hasil uji korelasi pearson

\begin{tabular}{|c|c|c|}
\hline \multicolumn{2}{|c|}{ Variabel } & $\begin{array}{c}\text { Variabel } \\
\text { tingkat } \\
\text { perceraian }\end{array}$ \\
\hline \multirow{3}{*}{$\begin{array}{l}\text { Rata-rata } \\
\text { usia kawin } \\
\text { pertama }\end{array}$} & $\begin{array}{l}\text { Pearson } \\
\text { Correlation }\end{array}$ & 0,25 \\
\hline & Sig. (2-tailed) & 0,131 \\
\hline & $\mathrm{N}$ & 38 \\
\hline \multirow{3}{*}{$\begin{array}{l}\text { Rata-rata } \\
\text { lama } \\
\text { sekolah }\end{array}$} & $\begin{array}{l}\text { Pearson } \\
\text { Correlation }\end{array}$ & 0,333 \\
\hline & Sig. (2-tailed) & 0,041 \\
\hline & $\mathrm{N}$ & 38 \\
\hline \multirow{3}{*}{ TPT laki-laki } & $\begin{array}{l}\text { Pearson } \\
\text { Correlation }\end{array}$ & 0,159 \\
\hline & Sig. (2-tailed) & 0,339 \\
\hline & $\mathrm{N}$ & 38 \\
\hline \multirow{3}{*}{$\begin{array}{l}\text { TPAK } \\
\text { perempuan }\end{array}$} & $\begin{array}{l}\text { Pearson } \\
\text { Correlation }\end{array}$ & $-0,88$ \\
\hline & Sig. (2-tailed) & 0,597 \\
\hline & $\mathrm{N}$ & 38 \\
\hline \multirow{3}{*}{$\begin{array}{l}\text { Persentase } \\
\text { penduduk } \\
\text { miskin }\end{array}$} & $\begin{array}{l}\text { Pearson } \\
\text { Correlation }\end{array}$ & $-0,466$ \\
\hline & Sig. (2-tailed) & 0,003 \\
\hline & $\mathrm{N}$ & 38 \\
\hline
\end{tabular}

Sementara itu, hasil korelasi menunjukkan bahwa rata-rata lama sekolah memiliki hubungan positif dengan tingkat perceraian yaitu sebesar 0,333. Arah positif tersebut menunjukkan bahwa semakin tinggi tingkat pendidikan penduduk, semakin tinggi tingkat perceraian. Hubungan keduanya termasuk signifikan $(p<0,05)$. Pada variabel tingkat pengangguran terbuka (TPT) laki-laki, hasil korelasi menunjukkan bahwa TPT laki-laki memiliki hubungan yang positif dengan tingkat perceraian yaitu sebesar 0,159 . Meskipun demikian, hubungan antara TPT laki-laki dan perceraian tidak signifikan $(p>0,05)$.

Pada variabel Tingkat Partisipasi Angkatan Kerja (TPAK) perempuan, hasil korelasi menunjukkan bahwa TPAK perempuan memiliki hubungan yang negatif dengan tingkat perceraian yaitu sebesar -0,88. Namun, hubungan antara TPAK perempuan dan perceraian tidak signifikan $(p>0,05)$. Untuk variabel persentase penduduk miskin, hasil korelasi menunjukkan bahwa persentase penduduk miskin memiliki hubungan yang negatif dengan tingkat perceraian yaitu sebesar $-0,466$. Hubungan antara persentase penduduk miskin dengan perceraian adalah signifikan $(p<0,05)$.

\section{PEMBAHASAN}

Hasil penelitian menunjukkan adanya peningkatan penduduk yang berstatus cerai hidup. Temuan ini sedikit kontradiktif dengan indeks kebahagiaan Jawa Timur dari tahun 2014 hingga 2017 yang mengalami peningkatan dari 68,7 persen menjadi 70,77 persen (BPS, 2019). Indeks kebahagiaan ini bahkan lebih tinggi dibandingkan rata-rata nasional yaitu 70,69 persen. Namun demikian, jika dilihat lebih dalam kepada salah satu komponen penyusun indeks kebahagiaan yakni pada sub dimensi keharmonisan keluarga, Jawa Timur masih berada di bawah rata-rata nasional yaitu 79,42 persen dibandingkan 80,05 persen (BPS, 2019). Komisi Nasional Perempuan menyebutkan bahwa angka perceraian di Jawa Timur pada tahun 2016 paling tinggi disebabkan oleh ketidakharmonisan sebanyak 21.599 kasus, kemudian diikuti oleh fakeor ekonomi sebanyak 20.989 kasus, dan tidak ada tanggung jawab sebanyak 17.975 kasus (Fajar, 2019). Informasi tersebut turut mendukung bahwa keharmonisan keluarga di Jawa Timur masih cukup rendah.

Penelitian ini menemukan bahwa tingkat perceraian di kota mengalami perubahan yang cukup signifikan. Pada tahun 2012, dari total sembilan kota di Jawa timur, terdapat empat kota yang memiliki persentase perceraian tinggi, kemudian berubah menjadi tujuh kota pada tahun 2017. Penelitian ini selaras dengan penelitian Gautier et al. (2005) yang menemukan bahwa tingginya perceraian di kota disebabkan oleh tingginya peluang penawaran. Penawaran yang dimaksud adalah ketersediaan penduduk lajang. Di pedesaan, penawaran bagi kedua pasangan lebih rendah sehingga kestabilan pernikahan lebih terjaga. Hal ini dikarenakan peluang mereka untuk mencari pasangan lain lebih kecil. Sebaliknya, tingginya perceraian di kota di Jawa Timur dapat disebabkan oleh besarnya penawaran atan peluang penduduk untuk mencari orang lain sebagai pasangan.

Penelitian juga menemukan bahwa tingkat perceraian yang tinggi banyak berada di wilayah yang dekat dengan pantai serta di daerah tapal kuda, sedangkan beberapa wilayah lainnya berdekatan dengan Jawa Tengah. Wilayah tapal kuda merupakan wilayah di Jawa Timur yang memiliki ciri khas budaya Pandalungan yang merupakan akulturasi berbagai macam budaya seperti Madura, Jawa, Islam, dan sebagainya. Banyak suku yang mendiami wilayah ini khususnya suku Madura dan Bali di daerah Banyuwangi yang membuat akulturasi kebudayaan menjadi bervariasi di wilayah tersebut. Selain itu, wilayah tapal kuda juga menjadi salah satu lokasi strategis perekonomian di wilayah laut Indonesia 
sehingga cenderung memiliki campuran kebudayaan yang diduga membawa perubahan dalam berbagai pola kehidupan masyarakatnya. Selain Pandalungan, wilayah-wilayah yang memiliki kebudayaan Mataraman, dan beberapa Arekan juga cenderung memiliki persentase perceraian yang tinggi. Hal ini menjadi unik mengingat Ambert (2009) mengungkapkan bahwa budaya menjadi salah satu faktor yang memengaruhi perceraian. Lebil lanjut Ambert menyebutkan bahwa akulturasi, modernisasi, dan liberalisasi sedikit banyak memiliki kontribusi terhadap perceraian di wilayahwilayah terkait.

Pengamatan lebih lanjut dapat dilihat pada wilayah yang memiliki tingkat perceraian tinggi di wilayah kota yaitu Kota Malang dan Batu, serta di kabupaten yaitu Kabupaten Nganjuk, Kediri, Lumajang, Probolinggo, Banyuwangi, dan Situbondo. Wilayah-wilayah tersebut selalu memiliki tingkat perceraian yang tinggi, baik pada tahun 2012 maupun 2017. Tingginya tingkat perceraian di wilayah tersebut cukup mengkhawatirkan dan membutuhkan perhatian yang lebih. Apabila diamati, wilayah-wilayah tersebut cenderung saling berdekatan. Wilayah seperti Kabupaten Kediri dan Nganjuk relatif dekat dengan kota madya seperti Kota Kediri, Malang, dan Batu. Tingginya perceraian di wilayah tersebut boleh jadi dipengaruhi oleh daerah-daerah pusat industri. Kota Malang termasuk dalam wilayah dengan kebudayaan Arekan. Pada wilayah ini terkenal terjadi industrialisasi yang pesat, yang mana membawa Kota Malang menjadi kota besar dengan pusat pendidikan, ekonomi, dan pariwisata. Kota tersebut juga dikenal sebagai pusat kebudayaan karena kondisi sosial masyarakatnya yang heterogen. Trovato (1986) menyebutkan bahwa wilayah yang mengalami perubahan sosial yang cepat dan mengalami industrialisasi dapat menarik migran dari wilayah lain, dan pada saat yang sama terjadi mobilitas dalam rangka mencari peluang hidup yang lebih baik. Berdasarkan pernyataan tersebut, tingginya tingkat perceraian di wilayah terkait dapat dijelaskan secara sederhana dalam skala makro meskipun pada dasarnya ada hal-hal lain yang lebih spesifik yang dapat menjelaskan tingginya perceraian di wilayah tersebut.

Sementara itu, wilayah seperti Kabupaten Lumajang, Probolinggo, Banyuwangi, dan Situbondo memiliki lokasi yang berdekatan dan merupakan satu wilayah kebudayaan yaitu Pandalungan. Pandalungan dikenal sebagai wilayah dengan akulturasi yang beragam antara budaya Jawa, Madura, bahkan Bali. Menariknya, Kabupaten Banyuwangi merupakan salah satu kabupaten dengan perceraian tertinggi di Indonesia yang menempati urutan tujuh besar pada tahun 2017. Kondisi tersebut menunjukkan bahwa ketidakharmonisan memang menjadi salah satu pendorong terjadinya perceraian di Jawa Timur, sejalan dengan dimensi keharmonisan keluarga Jawa Timur pada tahun 2017 yang masih di bawah rata-rata nasional. Bekerja keluar daerah/negeri juga terjadi di Kota Malang dan lama tidak pulang ke rumah menimbulkan ketidakstabilan di dalam rumah tangga sehingga pasangan kemudian bercerai. Hasil kajian ini sesuai dengan hasil penelitian Gautier et al. (2005) yang menemukan bahwa tingginya perceraian di kota disebabkan oleh tingginya penawaran. Penawaran yang dimaksud adalah ketersediaan dari penduduk lajang. Di pedesaan, penawaran akan lebih rendah terhadap kedua pasangan sehingga kestabilan pernikahan lebih terjaga. Hal ini dikarenakan peluang mereka untuk mencari orang lain menjadi lebih kecil. Teori dasar yang digunakan oleh Gautier et al. (2005) adalah teori pasar perkawinan. Kota dapat menyediakan pasar perkawinan yang potensial karena tingkat bertemunya para lajang lebih tinggi. Hal ini dipengaruhi oleh ukuran dari pasar perkawinan atau kepadatan penduduk yang tinggi di kota.

Penelitian ini menemukan bahwa rata-rata usia kawin pertama tidak berhubungan dengan perceraian. Hal ini bertentangan dengan penemuan sebelumnya (Ambert, 2009). Ambert (2009) menyebutkan faktor usia kawin pertama berpengaruh terhadap perceraian. Hasil penelitian ini menunjukkan bahwa korelasi antara perceraian dan usia kawin pertama tidak signifikan dan korelasi bernilai lemah $(p>0,05)$. Dengan demikian, rata-rata usia kawin pertama tidak memiliki hubungan yang kuat dan signifikan dengan perceraian.

Hasil penelitian ini juga menunjukkan bahwa rata-rata lama sekolah memiliki hubungan positif signifikan dengan tingkat perceraian. Semakin tinggi tingkat pendidikan penduduk, semakin tinggi tingkat perceraian. Pendidikan yang tinggi memberikan risiko perceraian yang tinggi akibat hilangnya utilitas yang diharapkan dari pernikahan (Bertian \& Härkönen, 2014). Hubungan pendidikan dengan perceraian ini dapat dijelaskan melalui dua perspektif. Berdasarkan perspektif pertama, pendidikan sebagai sumber daya manusia dapat meningkatkan manfaat ekonomi dari pasar tenaga kerja. Hal ini memungkinkan tingkat konsumsi yang lebih tinggi atau hidup yang lebih baik, namun di sisi lain, meningkatkan biaya pekerjaan rumah tangga, pengasuhan anak, dan sebagainya. Hal ini melemahkan pembagian 
tugas rumah tangga ke dalam pekerjaan pasar dan nonpasar dan rasa saling ketergantungan antara pasangan. Lebih lanjut, dalam kasus perempuan, hal ini akhirnya meningkatkan utilitas pilihan di luar pernikahan sehingga lebih memungkinkan terjadinya perceraian (Becker et al., 1977). Disisi lain, mereka yang memiliki pendidikan rendah lebih berisiko untuk mengalami perceraian dikarenakan pendidikan rendah dapat menjadi permasalahan ekonomi dalam keluarga.

TPT laki-laki memiliki hubungan positif dan lemah dengan tingkat perceraian. Hal ini menunjukkan bahwa semakin tinggi tingkat pengangguran laki-laki maka semakin meningkat perceraian. Hubungan kedua variabel tersebut sesuai dengan beberapa penelitian yang telah ada, akan tetapi kedua variabel tidak memiliki hubungan yang signifikan sehingga TPT laki-laki dinyatakan tidak memiliki hubungan dengan perceraian. Temuan ini berbeda dengan penelitian Goñalons-Pons dan Gangl (2018) yang melihat pengaruh pengangguran terhadap perceraian. Hilangnya pekerjaan menyebabkan keluarga berada dalam tekanan keuangan. Penelitian ini juga sejalan dengan temuan Difurio et al. (2012) yang menyebutkan bahwa variabel seperti pengangguran, pendapatan per kapita, agama, dan ekonomi regional memengaruhi tingkat perceraian di suatu wilayah. Amato dan Beattie (2011) menjelaskan pengaruh pengangguran terhadap perceraian menggunakan dua perspektif, yaitu perspektif stres psikososial dan perspektif biaya perceraian. Perspektif pertama mengarah kepada hubungan positif antara tingkat pengangguran dan perceraian, karena tidak adanya pendapatan memberikan tekanan finansial. Sementara itu, dari perspektif biaya perceraian, kehilangan pekerjaan dapat menghasilkan kendala ekonomi, membuat akses ke perceraian yang berpotensi lebih mahal menjadi lebih sulit sehingga peningkatan angka pengangguran berbanding terbalik dengan tingkat perceraian. Berdasarkan model stres keluarga, stresor ekonomi memengaruhi tekanan emosional pasangan dan pada akhirnya memengaruhi kepuasan pernikahan (Boertien \& Härkönen, 2014). Lebih lanjut, kaitan dengan gender, peningkatan partisipasi perempuan dalam angkatan kerja dapat memengaruhi kestabilan pernikahan (Dommaraju \& Jones, 2011; Wood, 1989). Peningkatan pekerjaan dan penghasilan perempuan dianggap mengurangi biaya perceraian dan memberikan istri alat ekonomi untuk mangakhiri perkawinan yang tidak bahagia yang menyebabkan meningkatnya konflik dalam keluarga.
Variabel selanjutnya yaitu TPAK perempuan yang memiliki hubungan negatif dan sangat lemah dengan tingkat perceraian. Berdasarkan hasil tersebut, peningkatan TPAK perempuan menurunkan tingkat perceraian. Temuan ini bertolak belakang dengan teori dan penelitian yang ada sebelumnya. Berdasarkan uraian sebelumnya juga telah diketahui bahwa wilayah dengan TPAK perempuan tinggi tidak semuanya memiliki tingkat perceraian yang tinggi, beberapa justru memiliki tingkat perceraian yang rendah. Selain itu, hubungan TPAK perempuan dengan tingkat perceraian tidak signifikan. Temuan ini berbeda dengan kajian GoñalonsPons dan Gangl (2018) yang menyatakan bahwa perempuan pernah kawin yang bekerja merupakan penduduk yang berisiko mengalami perceraian.

Temuan menarik dalam penelitian ini adalah mengenai faktor ekonomi dengan perceraian. Persentase penduduk miskin memiliki korelasi negatif dengan perceraian. Hal tersebut menunjukkan perceraian semakin banyak terjadi pada wilayah dengan jumlah penduduk miskin yang rendah. Dengan kata lain, semakin sejahtera/baik kondisi ekonomi penduduk di suatu wilayah maka potensi perceraian akan semakin meningkat. Temuan ini juga berbeda dengan kebanyakan penelitian yang telah ada sebelumnya. Namun demikian, temuan ini bisa dijelaskan karena telah terjadi pergeseran makna pernikahan dalam masyarakat saat ini. Masyarakat semakin toleran dengan perubahan pola pikir dan cara bersikap sehingga tekanan ekonomi bukan lagi menjadi pemicu terjadinya perceraian. Penurunan persentase penduduk miskin dengan peningkatan perceraian dapat dipahami sebagai bentuk kesejahteraan penduduk yang digambarkan dari kondisi ekonomi yang stabil atau pendapatan yang tinggi. Ambert (2009) menyebutkan bahwa perceraian yang terjadi saat ini cenderung mengarah kepada sikap individualisme sejak dua abad lalu yang berimplikasi baik secara langsung ataupun tidak langsung terhadap toleransi antar pasangan dalam perkawinan. Berdasarkan pertimbangan tersebut, Ambert tidak hanya memandang kemiskinan sebagai faktor pemicu perceraian, akan tetapi juga memberikan pandangan bahwa mobilitas vertikal, yang biasanya ditandai dengan peningkatan status sosial/ekonomi, juga memberikan risiko terhadap perceraian karena adanya upaya pengejaran materialisme yang mencerminkan nilai-nilai individualis yang tidak sesuai dengan kehidupan suami-istri yang harmonis. 
Salah satu bentuk pengejaran kemakmuran tersebut dapat dilihat dari adanya mobilitas. Asher dan Bloom (2008) menyebutkan bahwa salah satu faktor yang dapat digunakan untuk memprediksi perceraian di suatu wilayah adalah mobilitas, baik berpindahnya salah satu maupun kedua pasangan. Migrasi sering kali dijadikan sebuah solusi. Orang-orang bermigrasi dikarenakan alasan ekonomi dan keinginan untuk meningkatkan status ekonomi dan sosial. Kondisi ekonomi yang membaik kemudian tidak serta merta membuat pernikahan menjadi stabil. American Academy of Matrimonial Lawyer (Dickler, 2018) menyebutkan bahwa ketika ekonomi menguat dan pendapatan meningkat, banyak pasangan yang mungkin mengalami masalah sehingga perceraian akan cenderung meningkat, terutama pada saat terjadi ledakan ekonomi. Pendapatan yang tinggi meningkatkan gaya hidup di saat yang bersamaan biasanya terjadi ketika salah satu dari pasangan bekerja sehingga intensitas bertemu semakin berkurang dan akhirnya meningkatkan konflik. Masalah lain muncul berupa pengelolaan pendapatan. Atmaja (2014) melalui penelitiannya menyebutkan bahwa permasalahan yang biasanya dihadapi oleh keluarga tenaga kerja wanita (TKW) adalah pengelolaan pendapatan. Pendapatan yang didapatkan dari bekerja menjadi tenaga kerja asing belum mampu membawa keluarga kepada kesejahteraan yang sesungguhnya karena sebagian besar dari pendapatan digunakan untuk kepentingan konsumtif bukan produktif, sehingga gaya hidup meningkat (mewah) dan uang yang dimiliki habis untuk memenuhi peningkatan gaya hidup tersebut. Konflik lain yang muncul dari kondisi ini adalah pada keluarga yang ditinggalkan. Kondisi tersebut tidak hanya semata-mata terjadi dengan sendirinya di dalam keluarga tetapi dapat pula dipicu oleh lingkungan sekitar yang memiliki gaya hidup lebih pula.

\section{SIMPULAN DAN SARAN}

Penelitian ini menunjukkan bahwa tingkat perceraian di Jawa Timur cenderung mengalami peningkatan dari tahun ke tahun, yaitu dari 2,46 persen pada tahun 2012 menjadi 2,91 persen pada tahun 2017. Pola spasial perceraian di Jawa Timur sebagian berada di bagian tengah dan cenderung berada di bagian barat Jawa Timur, mayoritas pada wilayah dengan kebudayaan Mataraman dan Pandalungan. Selain adanya peningkatan angka perceraian, terdapat indikasi bahwa meskipun tingkat perceraian tersebar di seluruh kabupaten di Provinsi Jawa Timur namun ada kecenderungan tingkat perceraian semakin terkonsentrasi di wilayah-wilayah tertentu di bagian timur Jawa
Timur dan di wilayah kota madya. Hal ini terlihat dari meningkatnya indeks Hoover yang ditemukan.

Penelitian ini juga menemukan bahwa faktor sosial ekonomi yang memiliki hubungan signifikan dengan tingkat perceraian di Jawa Timur adalah rata-rata lama sekolah dan persentase penduduk miskin. Perceraian memiliki hubungan positif dengan rata-rata lama sekolah dan hubungan negatif dengan persentase penduduk miskin. Artinya, semakin tinggi tingkat pendidikan dan semakin makmur masyarakat di suatu wilayah, semakin besar tingkat perceraiannya. Berdasarkan temuan ini, Penulis merekomendasikan cara mengurangi tingkat perceraian di Jawa Timur yang dilakukan tidak hanya dengan memperbaiki tingkat pendidikan dan kemakmuran penduduk, tetapi juga memperbaiki kualitas pendidikan dan mendorong dekonsentrasi pendidikan dan kemakmuran.

Penelitian ini memiliki keterbatasan yaitu tingkat perceraian hanya dihitung berdasarkan jumlah penduduk perempuan yang pada saat pendataan berstatus cerai hidup dan tidak memperhitungkan mereka yang pernah bercerai kemudian menikah kembali. Peristiwa kawincerai yang terjadi tersebut tidak dapat dianalisis dalam penelitian ini karena keterbatasan data yang ada. Selain itu, penelitian ini juga memiliki keterbatasan untuk melihat dimensi perbedaan wilayah menurut karakteristik budaya, terutama dalam kasus Provinsi Jawa Timur yang memiliki empat wilayah kebudayaan yaitu Arekan, Mataraman, Madura, dan Pandalungan. Perbedaan karakteristik wilayah budaya tersebut menarik untuk dikaji terutama untuk melihat perbedaan budaya dalam wilayah yang berbeda-beda yang mungkin berpengaruh terhadap terjadinya perceraian yang ada di Provinsi Jawa Timur.

\section{UCAPAN TERIMA KASIH}

Penulis mengucapkan banyak terima kasih kepada Fakultas Geografi UGM yang telah memberikan pendanaan hibah penelitian mandiri dosen ini.

\section{DAFTAR PUSTAKA}

Amato, P. R. (2010). Research on divorce: Continuing trends and new developments. Journal of Marriage and Family, 72(3), 650-666. doi: 10.1111/j.17413737.2010.00723.x

Amato, P. R., \& Beattie, B. (2011). Does the unemployment rate affect the divorce rate? 
An analysis of state data 1960-2005. Social Science Research, 40(3), 705-715. doi: 10.1016/j.ssresearch.2010.12.012

Ambert, A.-M. (2009). Divorce: Facts, Causes, and Consequences Contemporary Family Trends (3rd ed.). Ottawa (US): Vanier Institute of the Family.

Arimurti, I., \& Nurmala, I. (2017). Analisis pengetahuan perempuan terhadap perilaku melakukan pernikahan usia dini di Kecamatan Wonosari Kabupaten Bondowoso. The Indonesian Journal of Public Health, 12(2), 249-262. doi: 10.20473/ijph.v12i1.2017.249-262

Asher, S. J., \& Bloom, B. L. (2008). Geographic mobility as a factor in adjustment to divorce. Journal of Divorce, 6(4), 69-84. doi: 10.1300/J279v06n04\05

Atmaja, H. T. (2014). Keberadaan keluarga TKW Jawa Timur berbasis arena produksi kultural. Forum IImu Sosial, 41(1), 1-8. doi: $10.15294 /$ fis.v41i1.5375

Becker, G. S. (1993). A Treatise on the Family Enlarged Edition. Massachusetts (US): Harvard University Press.

Becker, G. S., Landes, E. M., \& Michael, R. T. (1977). An economic analysis of marital instability. Journal of Political Economy, 85(6), 1141-1187. Retrieved from http://www.jstor.org/stable/1837421

Boertien, D., \& Härkönen, J. (2014). Less education, more divorce: Explaining the inverse relationship between women's education and divorce. In Stockholm Research Reports in Demography. Retrieved from https://www.suda.su.se/polopoly_fs/1.290 338.1467895103!/menu/standard/file/SRR D_2014_11.pdf

[BPS] Badan Pusat Statistik. (2008). Rata-rata lama sekolah penduduk Jawa Timur menurut kabupaten/kota 2010-2016. Jawa Timur (ID): Badan Pusat Statistik.

[BPS] Badan Pusat Statistik. (2012). Hasil survei sosial ekonomi nasional tahun 2012 Provinsi Jawa Timur. Jawa Timur (ID): Badan Pusat Statistik.

[BPS] Badan Pusat Statistik. (2013). Hasil survei sosial ekonomi nasional tahun 2013 Provinsi Jawa Timur. Jawa Timur (ID): Badan Pusat Statistik.

[BPS] Badan Pusat Statistik. (2014). Hasil survei sosial ekonomi nasional tahun 2014 Provinsi Jawa Timur. Jawa Timur (ID): Badan Pusat Statistik.
[BPS] Badan Pusat Statistik. (2015). Statistik kesejahteraan rakyat Provinsi Jawa Timur Tahun 2015. Jawa Timur (ID): Badan Pusat Statistik.

[BPS] Badan Pusat Statistik. (2017a). Jumlah nikah, talak dan cerai, serta rujuk tahun 2012-2015. Jakarta (ID): Badan Pusat Statistik.

[BPS] Badan Pusat Statistik. (2017b). Statistik Indonesia 2017. Jakarta (ID): Badan Pusat Statistik.

[BPS] Badan Pusat Statistik. (2017c). Statistik kesejahteraan rakyat Provinsi Jawa Timur Tahun 2017. Jawa Timur (ID): Badan Pusat Statistik.

[BPS] Badan Pusat Statistik. (2018). Statistik kesejahteraan rakyat Provinsi Jawa Timur Tahun 2018. Jawa Timur (ID): Badan Pusat Statistik.

[BPS] Badan Pusat Statistik. (2019). Statistik kesejahteraan rakyat Provinsi Jawa Timur Tahun 2019. Jawa Timur (ID): Badan Pusat Statistik.

[BPS] Badan Pusat Statistik. (2019). Statistik indeks kebahagiaan subdimensi Jawa Timur. Jawa Timur (ID): Badan Pusat Statistik.

[BPS] Badan Pusat Statistik. (2020). Statistik kesejahteraan rakyat Provinsi Jawa Timur Tahun 2020. Jawa Timur (ID): Badan Pusat Statistik.

Choiriah, M. (2016). Indonesia darurat perceraian! Retrieved from https://www.merdeka.com/khas/ indonesia-darurat-perceraian-trenperceraian-meningkat-1.html.

Clark, W., \& Crompton, S. (2006). Till death do us part? The risk of first and second marriage dissolution. Retrieved from https://www150.statcan.gc.ca/n1/pub/11008-x/2006001/pdf/9198-eng.pdf

Dewi, P. S., \& Utami, M. S. (2018). Subjective eell-being anak dari orang tua yang bercerai. Jurnal Psikologi, 35(2), $194-212$. doi: 10.22146/jpsi.7952

Dickler, J. (2018). Being rich may increase your odds of divorce. Retrieved from https://www.cnbc.com/2018/10/10/beingrich-may-increase-your-odds-ofdivorce.html

Diekmann, A. (1994). Is women's labor force participation caused by increasing divorce risks? Soziale Welt, 45(1), 83-97.

DiFurio, F., Lewis, W., \& Goode, T. (2012). A 
Regional analysis of divorce rates. International Journal of Business and Social Science, 3(13), 38-43. Retrieved from

http://www.ijbssnet.com/journals/Vol_3_N 0_13_July_2012/4.pdf

Dommaraju, P., \& Jones, G. (2011). Divorce trends in Asia. Asian Journal of Social Science, 39(6), 725-750. doi: 10.1163/156853108X327038

Fajar, A. (2019). Angka Cerai di Kalangan Guru Jatim Tinggi, Khofifah Ungkap Penyebabnya. Retrieved from https://jatim.idntimes.com/news/indonesia/ ardiansyah-fajar/angka-cerai-di-kalanganguru-jatim-tinggi-khofifah-ungkappenyebabnya

Fischer, C. S. (1975). Toward a subcultural theory of urbanism. American Journal of Sociology, 80(6), 1319-1341. Retrieved from http://www.jstor.org/stable/2777297

Florida, R. (2008). Who's your city?: How the creative economy li making Where to live the most important decision of your life. New York (US): Basic Books.

Frisco, M. L., \& Williams, K. (2003). Perceived housework equity, marital happiness, and divorce in Dual-Earner Households. Journal of Family Issues, 24(1), 51-73. doi: 10.1177/0192513X02238520

Gautier, P. A., Svarer, M., \& Teulings, C. (2010). Marriage and the city: Search frictions and sorting of singles. Journal of Urban Economics, 67(2), 206-218. doi: 10.1016/j.jue.2009.08.007

González-Val, R., \& Marcén, M. (2018). Unemployment, marriage and divorce. Applied Economics, 50(13), 1495-1508. doi: $10.1080 / 00036846.2017 .1366642$

Hackstaff, K. B. (1999). Introduction: Watershed in the Meaning of Marriage (K. B. Hackstaff (Ed.); I). Philadelphia (US): Temple University Press.

Hou, F., \& Omwanda, L. O. (1997). A multilevel analysis of the connection between female labour Force participation and divorce in Canada, 1931-1991. International Journal of Comparative Sociology, 38(3-4), 271288. doi: 10.1163/002071597X00063

Khotimah, K., \& Ahmad, M. (2019). Dari sakral ke profan: Pergeseran budaya perceraian di Kabupaten Cilacap. Muwazah-Jurnal Kajian Gender, 11(1), 83-100. doi: 10.28918/muwazah.v11i1.1893

Kustini, \& Rosidah, I. (Eds.). (2016). Ketika
Perempuan Bersikap: Tren Cerai Gugat Masyarakat Muslim. Jakarta (ID): Kementerian Agama RI, Badan Litbang dan Diklat, Puslitbang Kehidupan Keagamaan.

Matondan, A. (2014). Faktor-faktor yang mengakibatkan perceraian dalam perkawinan. Jurnal IImu Pemerintahan dan Sosial Politik, 2(2), 141-150. doi: 10.31289/jppuma.v2i2.919

Rais, I. (2014). Tingginya angka cerai gugat (khulu') di Indonesia: Analisis kritis terhadap penyebab dan alternatif solusi mengatasinya. Al-'Adalah, 12(1), 191-204. doi: 10.24042/adalah.v12i1.183

Rogerson, P., \& Plane, D. (2013). The Hoover Index of population concentration and the demographic components of change: An article in memory of Andy Isserman. International Regional Science Review, 36, 97-114. doi: 10.1177/0160017612440811

Sa'adah, M. (2018). Gender dan perceraian: Kasus cerai gugat di Pengadilan Agama Bekasi. Muwazah-Jurnal Kajian Gender, 10(1), 47-57. doi: 10.28918/muwazah.v10i1.1314

Setyaningsih, P. (2013). Pekerja perempuan dan segmentasi pasar kerja menurut wilayah kebudayaan di Provinsi Jawa Timur. Yogyakarta (ID): Universitas Gadjah Mada.

Thalib, A., \& Lestari, M. (2017). Tingginya tingkat gugat cerai di Pengadilan Agama Pekanbaru. Hukum Islam, 17(1), 30-51. doi: 10.24014/hi.v17i1.3961

Trent, K., \& South, S. J. (1989). Structural determinants of the divorce date: A crosssocietal analysis. Journal of Marriage and Family, 51(2), 391-404. Retrieved from http://www.jstor.org/stable/352502

Tristanto, A. (2020). Perceraian di masa pandemi Covid-19 dalam perspektif ilmu sosial. Sosio Informa, 6(3), 292-304. doi: 10.33007/inf.v6i3.2417

Uddin, M. G., \& Hosain, M. M. (2013). Factors affecting marital instability and its impact on fertility in Bangladesh. ASA University Review, 7(2), 35-41. Retrieved from http://www.asaub.edu.bd/data/asaubrevie w/v7n2sl4.pdf

Wijayanti, U. T. (2021). Analisis faktor penyebab perceraian pada masa pandemi Covid-19 di Kabupaten Banyumas. Jurnal IImu Keluarga \& Konsumen, 14(1), 14-26. doi: 10.24156/jikk.2021.14.1.14 
Wood, F. (1989). Personal Voices: Chinese Women in the 1980s. By Emily Honig and Gail Hershatter. [Stanford: Stanford University Press, 1988. 387 pp.]. The China Quarterly, 119, 659-659. doi: $10.1017 /$ S0305741000023201
Yodanis, C. (2005). Divorce culture and marital gender equality: A cross-national study. Gender and Society, 19(5), 644-659. Retrieved from http://www.jstor.org/stable/27640833 